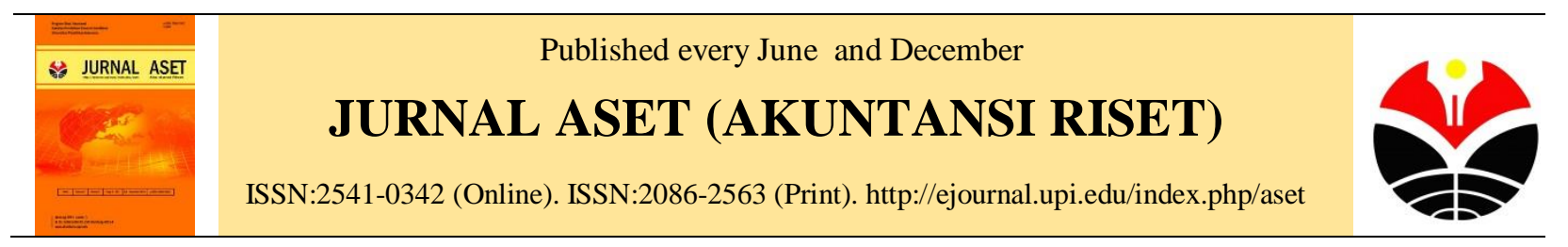

\title{
Pengaruh Tenur Audit, Rotasi Audit Dan Reputasi Kap Terhadap Kualitas Audit (Studi Pada Perusahaan Manufaktur Yang Terdaftar Di Bursa Efek Indonesia Tahun 2011-2014)
}

\author{
Irsyad Fauzan Prasetia ${ }^{1}$ Rozmita Dewi Yuniarti Rozali ${ }^{2}$ \\ Program Studi Akuntansi, Fakultas Pendidikan Ekonomi dan Bisnis, \\ Universitas Pendidikan Indonesia, Bandung, Indonesia
}

\begin{abstract}
This study aims to find out how audit wells, audit rotation and reputation of KAP to audit quality at manufacturing companies listed in Indonesia Stock Exchange in 2011-2014. The research method used in this research is verifikatif method. The population in this study is a manufacturing company listed on the Indonesia Stock Exchange since 2011 until 2014, while for sampling using purposive sampling method. The data used are secondary data collected by documentation technique. In analyzing the data, this research uses statistical test of panel data regression with common effect model model. Based on the calculation of panel data regression analysis with the help of Eviews 9 software resulted that the reputation of KAP has a positive effect on audit quality, while audit and audit rotation have negative effect on audit quality.
\end{abstract}

Keywords: Audit Audit, Audit Rotation, KAP Reputation, and Audit Quality.

Abstrak. Penelitian ini bertujuan untuk mengetahui bagaimana tenur audit, rotasi audit dan reputasi KAP terhadap kualitas audit pada perusahaan manufaktur yang terdaftar di Bursa Efek Indonesia tahun 20112014. Metode penelitian yang digunakan dalam penelitian ini adalah metode verifikatif. Populasi pada penelitian ini adalah perusahaan manufaktur yang terdaftar di Bursa Efek Indonesia sejak tahun 2011 sampai dengan tahun 2014, sedangkan untuk pengambilan sampel menggunakan metode purposive sampling. Data yang digunakan adalah data sekunder yang dikumpulkan dengan teknik dokumentasi. Dalam menganalisis data, penelitian ini menggunakan pengujian statistik regresi data panel dengan model common effect model. Berdasarkan perhitungan analisis regresi data panel dengan bantuan software Eviews 9 menghasilkan bahwa reputasi KAP berpengaruh positif terhadap kualitas audit, sedangkan tenur dan rotasi audit berpengaruh negative terhadap kualitas audit.

Kata Kunci: Tenur Audit, Rotasi audit, Reputasi KAP, dan Kualitas audit.

Corresponding Author. Email. irsyadfauzanp@gmail.com ${ }^{1}$ rozmita.dyr@upi.edu ${ }^{2}$

How to Cite This Article. Prasetia, F.I., \& Rozali, Y.D.R. (2016). Pengaruh Tenur Audit, Rotasi Audit Dan Reputasi Kap Terhadap Kualitas Audit (Studi Pada Perusahaan Manufaktur Yang Terdaftar Di Bursa Efek Indonesia Tahun 2011-2014). Jurnal Akuntansi Riset.. Program Studi Akuntansi. Fakultas Pendidikan Ekonomi dan Bisnis Universitas Pendidikan Indonesia, 8 (1), 49-60. Retrieved from http://ejournal.upi.edu/index.php/aset/article/view/4020

History of article. Received: January 2016, Revision: Maret 2016, Published: June 2016

Online ISSN: 2541-0342. Print ISSN: 2086-2563. DOI : 10.17509/jaset.v8i1.4020

Copyright@2016. Jurnal ASET (Akuntansi Riset) Program Studi Akuntansi FPEB UPI 


\section{PENDAHULUAN}

Perbedaan kepentingan diantara investor (principal) dan pemilik perusahaan (agen) menyebabkan adanya konflik keagenan yang dijelaskan dalam teori agensi oleh Jensen dan Meckling (1976). Teori ini lahir karena disebabkan adanya asimetri informasi antara agen dan prinsipal. Salah satu cara yang menghubungkan antara pihak investor dan perusahaan adalah dengan cara menyajikan laporan keuangan. Laporan keuangan merupakan media utama bagi perusahaan untuk menyampaikan informasi keuangan mengenai pertanggungjawaban pihak manajemen. Informasi tersebut harus memiliki kualitas yang dapat diandalkan karena dapat berguna untuk proses pengambilan keputusan.

Audit laporan keuangan merupakan kebutuhan perusahaan dan pihak manajemen perusahaan untuk mendapatkan kepercayaan publik. Auditing diharapkan dapat meminimalkan asimetri informasi yang terjadi antara manajer dan investor karena dengan adanya pihak ketiga akan memverifikasi keabsahan laporan keuangan. Untuk menghasilkan keyakinan klien terhadap auditor, maka kualitas yang dihasilkan harus baik. Kualitas dari sebuah proses audit merupakan hal yang sangat penting untuk menjamin bahwa laporan keuangan dapat digunakan sebagai dasar pengambilan keputusan dan dapat dipercaya oleh masyarakat maupun pihak ketiga lainnya. Dari sudut pandang auditor, audit dianggap berkualitas apabila auditor memperhatikan standar umum audit yang tercantum dalam pernyataan standar auditing meliputi mutu profesional (profesional qualities) auditor independen, pertimbangan (judgement) yang digunakan dalam pelaksanaan audit dan penyusunan laporan keuangan auditan, Maharani (2014).

Auditor Independen diharapkan mampu mengevaluasi laporan secara wajar sesuai prinsip-prinsip akuntansi yang berlaku umum di Indonesia. Banyaknya kasus kecurangan laporan keuangan yang melibatkan Auditor Independen menimbulkan keraguan mengenai kualitas dari hasil audit. Kasus yang terjadi di Amerika Serikat yaitu Koss Corporation di tahun 2010 melibatkan auditor Grant Thornton karena auditor dianggap tidak mampu mendeteksi penipuan yang dilakukan oleh wakil presiden keuangan perusahaan selama periode lima tahun (Weiner 2012). Di Indonesia, kasus yang melibatkan PT. Kimia Farma Tbk dan auditor KAP Hans Tuanakotta dan Mustofa juga disebabkan karena resiko audit yang ditentukan auditor tidak berhasil mendeteksi adanya penggelembungan laba (Bapepam, 2002). Dan juga pada bulan Februari tahun 2015 lalu PT Inovisi Infracom Tbk (INVS) mendapat sanksi penghentian sementara (suspen) perdagangan saham oleh PT Bursa Efek Indonesia (BEI). Sanksi ini diberikan karena ditemukan banyak kesalahan di laporan kinerja keuangan perusahaan kuartal III-2014. Perdagangan saham Inovisi masih dihentikan sejak Jumat 13 Februari 2015. BEI menemukan ada delapan kesalahan dalam laporan keuangan sembilan bulan 2014. Aksi pembekuan saham ini diprotes investor karena harga saham Inovisi tidak berubah dan investor tidak bisa melepas maupun membeli saham Inovisi. Bahkan ada investor ritel yang dananya nyangkut $\mathrm{Rp}$ 70 juta di saham Inovisi tanpa bisa berbuat apa-apa (finance.detik.com). Kasus ini juga melibatkan auditor dari KAP Jamaludin, Ardi, Sukimto, dan rekan karena auditor dianggap tidak mampu mendeteksi kesalahan dalam laporan kinerja keuangan PT. Inovisi Infracom Tbk (INVS). Independesi auditor dapat dipengaruhi oleh lama waktu seorang auditor bekerja untuk seorang klien, sehingga semakin lama hubungan kerja antara AP maupun KAP dengan seorang klien akan mempengaruhi independensinya, sedangkan dari segi kompetensi adanya rotasi AP dapat menyebabkan penurunan kualitas audit (Siregar et al. 2011). Penurunan kualitas audit ini disebabkan karena auditor harus menghadapi perusahaan baru sebagai 
kliennya maka akan diperlukan lebih banyak waktu baginya untuk mempelajari terlebih dahulu klien barunya daripada ketika auditor melanjutkan penugasan dari klien terdahulunya (Chen et al. 2004 dalam Siregar et al. 2011). Hal ini dapat pula berpengaruh terhadap kualitas audit, semakin lama seorang auditor mengaudit seorang klien maka kompetensi auditor akan semakin baik karena auditor telah memahami secara lebih mendalam mengenai bisnis yang dijalankan oleh kliennya.

Kualitas audit tercermin dari kemampuan auditor dalam memahami bisnis proses dan sistem akuntansi perusahaan. Pemahaman auditor akan hal tersebut didasari oleh pemahaman atas standar akuntansi yang berlaku (Apandi, 2014). Kualitas audit pada berbagai penelitian sebelumnya sering dikaitkan dengan ukuran KAP. KAP besar identik dengan KAP bereputasi tinggi yang dalam hal ini menunjukkan kemampuan auditor untuk bersiKAP independen dalam melaksanakan audit secara professional, sebab KAP menjadi kurang tergantung secara ekonomi kepada klien. Klien juga kurang dapat mempengaruhi opini auditor. Penyebab dari hal tersebut adalah kelebihan yang dimiliki oleh KAP besar yaitu besarnya jumlah dan ragam klien yang ditangani KAP, banyaknya ragam jasa yang ditawarkan, adanya afiliasi internasional, dan banyaknya jumlah staf audit dalam suatu KAP (Giri, 2010).

Berdasarkan latar belakang dan fenomena yang ada, maka pada penelitian penulis ini merumuskan masalah bagaimana pengaruh tenur audit terhadap kualitas audit pada perusahaan manufaktur yang terdaftar di BEI, bagaimana pengaruh rotasi terhadap kualitas audit pada perusahaan manufaktur yang terdaftar di BEI, bagaimana pengaruh reputasi KAP terhadap kualitas audit pada perusahaan manufaktur yang terdaftar di BEI. Dan tujuan penelitian ini adalah untuk mengetahui bagaimana pengaruh tenur audit terhadap kualitas audit pada perusahaan manufaktur yang terdaftar di BEI, bagaimana pengaruh rotasi terhadap kualitas audit pada perusahaan manufaktur yang terdaftar di BEI, bagaimana pengaruh reputasi KAP terhadap kualitas audit pada perusahaan manufaktur yang terdaftar di BEI.

\section{KAJIAN LITERATUR \\ Teori Keagenan (Agency Theory)}

Jensen dan Meckling

mendefinisikan teori agensi sebagai hubungan keagenan suatu kontrak, dimana satu orang atau lebih (prinsipal) meminta pihak lainnya (agen) untuk melaksanakan sejumlah pekerjaan atas nama prinsipal, yang melibatkan pendelegasian beberapa wewenang pembuatan keputusan kepada agen. Menurut Eisenhardt (1989), teori agensi menggunakan tiga asumsi sifat manusia yaitu:

1. Manusia pada umumya mementingkan diri sendiri (self interest);

2. Manusia memiliki daya pikir terbatas mengenai persepsi masa mendatang (bounded rationality);

3. Manusia selalu menghindari risiko (risk averse).

Dalam teori agensi, dapat diasumsikan bahwa masing-masing individu cenderung untuk mementingkan diri sendiri. Hal ini menimbulkan adanya konflik kepentingan antara prinsipal dan agen. Prinsipal memiliki kepentingan untuk memaksimalkan keuntungan mereka sedangkan agen memiliki kepentingan untuk memaksimalkan pemenuhan kebutuhan ekonomi dan psikologisnya. Konflik akan terus meningkat karena prinsipal tidak dapat mengawasi aktivitas agen sehari-hari, yaitu untuk memastikan bahwa agen telah bekerja sesuai dengan keinginan dari prinsipal. Hal ini akan menyebabkan ketidakseimbangan informasi antara agen dan prinsipal.

Potensi konflik yang terjadi dalam hubungan kontraktual antara berbagai pihak yang berkepentingan dalam perusahaan disebabkan oleh perbedaan tujuan masing-masing berdasarkan posisi dan kepentingannya. Konflik seperti ini muncul ketika principal kesulitan untuk 
memastikan bahwa agen bertindak yang terbaik untuk kepentingan (memaksimumkan kesejahteraan) principals, yaitu dengan munculya konflik kepentingan dan adanya asimetri informasi (Sopian,2015).

\section{Tenur Audit}

Tenur audit adalah masa perikatan (jangka waktu) antara auditor dengan klien terkait jasa audit yang disepakati. Tenure menjadi perdebatan pada saat tenure audit yang dilakukan terlalu singkat dan tenure audit yang dilakukan dalam jangka waktu lama (Fierdha et al 2014). Tenure sendiri dapat berdampak pada kinerja auditor pada perusahaan klien seperti hubungan emosional auditor dengan klien, independensi, fee audit, profesionalisme kerja, kompetensi, dsb.

Ada pandangan yang berbeda mengenai dampak dari lamanya hubungan antara klien dengan auditor. Pihak-pihak yang tidak setuju dengan ketentuan rotasi wajib berpendapat bahwa pembatasan hubungan jangka panjang antara auditor dan manajer akan menurunkan independensi auditor. Selain itu, ketentuan ini akan menimbulkan switching cost yang besar dan menurunkan kualitas audit. Keberatan atas ketentuan rotasi wajib disampaikan oleh GAO (General Accounting Office). Manfaat yang timbul dari ketentuan rotasi wajib tidak mampu menutupi cost perpindahan dan cost lainnya yang terjadi dalam pengauditan. Rotasi mandatori diperlukan jika ketentuan SOX di Amerika Serikat tidak dapat meningkatkan kualitas audit (GAO, 2003 dalam Giri, 2010).

\section{Rotasi Audit}

Menurut Fierdha et al (2014) rotasi audit merupakan pergantian akuntan publik dimana akuntan publik di Indonesia hanya dapat mengaudit laporan keuangan perusahaan maksimal tiga tahun berturutturut.

Penerapan ketentuan rotasi wajib dilandasi alasan teoritis bahwa penerapan rotasi wajib bagi auditor dan KAP diharapkan akan meningkatkan independensi auditor baik secara tampilan maupun secara fakta. Pembatasan tenure auditor merupakan usaha untuk mencegah auditor terlalu dekat berinteraksi dengan klien sehingga mengganggu independensinya. Pembatasan tenure juga diharapkan agar tidak terjadi eskalasi komitmen auditor terhadap penyimpangan yang dilakukan oleh klien (Giri, 2010).

Rotasi Auditor, dapat diartikan sebagai pergantian kantor akuntan publik yang memberikan jasa audit terhadap kliennya. Rotasi auditor terjadi karena dua hal yaitu sukarela (voluntary) dan wajib (mandatory). Rotasi auditor mandatory terjadi karena auditor mengundurkan diri atau auditor dipecat oleh klien.

\section{Reputasi Kantor Akuntan Publik}

Reputasi KAP menunjukkan kemampuan auditor untuk bersikap independen dan melaksanakan audit secara profesional, sebab KAP besar (Big) 4 menjadi kurang tergantung secara ekonomi kepada klien. Klien juga kurang dapat mempengaruhi opini auditor. KAP besar juga cenderung tidak berkompromi atas kualitas audit, sehingga dapat memberikan kualitas audit yang lebih baik daripada KAP kecil (non Big 4). KAP besar cenderung memberikan opini kebangkrutan perusahaan klien (Lenox, 1999 dalam Giri, 2010). KAP berafiliasi dengan KAP internasional dipakai sebagai proksi reputasi KAP. KAP bereputasi menjelaskan adanya sikap independensi auditor dalam melaksanakan tugas audit. Auditor yang berafiliasi dengan KAP internasional akan berpengaruh negatif terhadap kualitas audit yang diukur dengan akrual (Becker et al 1998).

Dalam (Theodorus, 2011), PPAJP

(Pusat Pembinaan Akuntan dan Jasa Penilai) mengelompokkan KAP dalam tiga kategori, yaitu :

1. KAP dengan afiliasi Big Four;

2. KAP dengan afiliasi non Big Four;

3. KAP tanpa kerja sama internasional.

KAP Big 4 ataupun KAP Internasional dianggap cenderung memberikan kualitas audit yang baik. Ada empat kelebihan skala auditor menurut 
Firth \& Liau Tan (1998 dalam Rossieta dan Wibowo (2009)), yaitu:

1. Besarnya jumlah dan ragam klien yang ditangani KAP;

2. Banyaknya ragam jasa yang ditawarkan;

3. Luasnya cakupan geografis, termasuk adanya afiliasi international; dan

4. Banyaknya jumlah staf audit dalam suatu KAP.

Reputasi KAP dalam penelitian ini diukur dengan menggunakan kelompok KAP afiliasi big four, KAP afiliasi non big four dan KAP tanpa afiliasi international. Panjaitan (2014) menjelaskan ada empat KAP lokal yang berafiliasi dengan The Big Four Auditors yaitu:

1) KAP Purwantono, Sarwoko, Sandjaja berafiliasi dengan Ernst \&Young,

2) KAP Osman Bing Satrio dan Rekan berafiliasi dengan Deloitte Touche Tohmatsu,

3) KAP Siddharta dan Widjaja berafiliasi dengan KPMG,

4) KAP Tanudireja Wibisana \& Rekan berafiliasi dengan

PricewaterhouseCoopers.

\section{Kualitas Audit}

Kualitas audit dijadikan sebagai dasar baik-buruknya sebuah laporan keuangan yang telah di audit, kualitas audit di dalam penelitian ini dinilai menggunakan nilai akrual diskrisioner. Kualitas laporan audit ini sendiri dipengaruhi oleh beberapa faktor misalnya independensi auditor, sehingga bagi auditor kualitas audit dinilai bedasarkan apa yang mereka kerjakan sesuai dengan standart professional yang ada dengan tujuan untuk meminimalisir resiko yang ada dan bagi para pengguna laporan keuangan kualitas audit terjadi bila auditor memberikan jaminan bahwa dalam laporan keuangan tersebut sudah tidak ada salah saji yang material serta kecurangan-kecurangan.

Dalam mendefinisikan kualitas audit, para peneliti akuntansi mengidentifikasi berbagai dimensi dari kualitas audit. Dengan banyaknya dimensi yang diteliti membuat definisi kualitas audit juga berbeda - beda.
Definisi - definisi tersebut antara lain diberikan oleh DeAngelo (1981) dalam Apandi (2014) bahwa kualitas audit didefinisikan sebagai kemampuan auditor untuk menemukan dan melaporkan adanya kesalahan dalam proses akuntansi pada perusahaan yang diaudit. Sedangkan DeAngelo (1991) dalam Mgbame, et al (2012) mendefinisikan kualitas audit sebagai probabilitas bahwa auditor akan menemukan baik dan jujur melaporkan kesalahan material, keliru dan kelalaian terdeteksi dalam sistem akuntansi klien. Kualitas audit akan tercermin dari kemampuan auditor dalam memahami bisnis proses dan sistem akuntansi perusahaan. Lee, Liu dan Wang (1999 dala Wibowo \& Rossieta 2009) mendefinisikan kualitas audit sebagai probabilitas bahwa auditor tidak akan melaporkan laporan audit dengan opini wajar tanpa pengecualian untuk laporan keuangan yang mengandung salah saji material. (Boynton, et al, 2002 hlm. 329) mendefinisikan sebagai kemampuan auditor bekerja sesuai standar professional yang ada, dapat menilai resiko bisnis auditee dengan tujuan untuk meminimalisasi resiko litigasi, dapat meminimalisasi ketidakpuasan auditee dan menjaga kerusakan reputasi auditor.

\section{METODE PENELITIAN}

Objek penelitian dalam penelitian ini adalah tenur audit, rotasi audit, reputasi KAP dan kualitas audit. Penelitian ini akan dilakukan pada pada perusahaan manufaktur yang listing di Bursa Efek Indonesia (BEI). Adapun periode tahun buku yang diteliti adalah Tahun 20112014. Dengan menggunakan objek tersebut, peneliti ingin menganalisa bagaimana tenur audit, rotasi audit, reputasi KAP terhadap kualitas audit. Penelitian ini dirancang dengan metode penelitian verifikatif dengan pendekatan kuantitatif. Dalam penelitian ini terdapat empat variabel yaitu tenur audit, rotasi audit, reputasi KAP dan kualitas audit 
Populasi dalam penelitian ini adalah perusahaan-perusahaan manufaktur yang terdaftar di Bursa Efek Indonesia tahun 20112014. Teknik sampling yang digunakan dalam penelitian ini adalah non-probability sampling dengan pendekatan sampling purposive. Berdasarkan metode purposive sampling diperoleh 92 sampel per satu tahun pengamatan yang memenuhi kriteria yang telah penulis tetapkan yaitu :

1. Perusahaan manufaktur yang terdaftar di Bursa Efek Indonesia selama tahun 20112014.

2. Perusahaan manufaktur yang melaporkan informasi keuangan secara lengkap dan berturut-turut selama tahun 2011-2014..

3. Data perusahaan manufaktur berupa Laporan Keuangan yang telah diaudit oleh auditor independen.

4. Laporan keuangan dilaporkan dalam mata uang rupiah
Penelitian ini menggunakan data sekunder bersumber dari laporan keuangan tahunan (annual report) perusahaan manufaktur yang terdaftar di BEI pada tahun 2011 - 2014. Teknik pengumpulan data menggunakan teknik dokumentasi. Analisis data dalam penelitian ini menggunakan data panel (pool data). Dikarenakan pada penelitian ini menggunakan data jenis time series dan juga cross section. Agar lebih akurat dalam melakukan analisisnya, maka dari itu penulis menggunakan regresi data panel.

\section{HASIL DAN PEMBAHASAN Statistik Deskriptif}

Statistik deskriptif disajikan untuk memberikan informasi karakteristik variabel penelitian khususnya mengenai rata-rata (mean), maksimum, minimum dan standar deviasi.

Tabel 1. Statistik Deskriptif

\begin{tabular}{|c|c|c|c|c|c|}
\hline Variabel & N & Minimum & Maximum & Mean & $\begin{array}{c}\text { Std. } \\
\text { Deviation }\end{array}$ \\
\hline Akrual Lancar & 368 & $-1,76$ & 4,03 & 0,079 & 0,47925 \\
\hline Tenur Audit & 368 & 1,00 & 4,00 & 1,497 & 0,68459 \\
\hline Rotasi Audit & 368 & 0,00 & 1,00 & 0,410 & 0,49256 \\
\hline Reputasi KAP & 368 & 1,00 & 3,00 & 2,258 & 0,65297 \\
\hline
\end{tabular}

Sumber : data diolah

Tabel 1 menjelaskan nilai statistik deskriptif dari masing - masing variabel yang ada dalam penelitian ini. Variabel kualitas audit diukur dengan proksi akrual lancer, dari 368 sampel penelitian kualitas audit memiliki nilai minimum sebesar $-1,76$ (dalam triliun), nilai maximum 4,03 (dalam triliun) dan memiliki nilai rata - rata sekitar 0,079 (dalam triliun). Nilai standar deviasi dari kualitas audit sebesar 0,47925.

Variabel tenur audit memiliki nilai minimum sebesar 1 satuan dan memiliki nilai maksimum sebesar 4 yang artinya dari 368 sampel perusahaan, tenur audit terpanjang sebesar 4 tahun. Untuk rata-rata dari tenur audit sebesar 1,497 dan memiliki standar deviasi sebesar 0,68459.
Variabel rotasi audit memiliki nilai minimum sebesar 0 satuan dan memiliki nilai maksimum sebesar 1 . Untuk rata-rata dari rotasi audit sebesar 0,410 dan memiliki standar deviasi sebesar 0,49256. Variabel reputasi KAP memiliki nilai minimum sebesar 1 satuan dan memiliki nilai maksimum sebesar 3. Untuk rata-rata dari tenur audit sebesar 2,258 yang artinya dari 368 sampel perusahaan, rata - rata KAP yang dipakai oleh klien. perusahaan manufaktur adalah KAP dengan afiliasi internasional big four maupun non big four. Nilai standar deviasi dari reputasi KAPsebesar 0,65297 


\section{Uji Regresi Data Panel}

Tabel 2. Hasil Pengujian Common Effect Model Regresi Data Panel

Dependent Variable: AL?

Method: Pooled Least Squares

Date: 05/02/16 Time: 13:38

Sample: 20112014

Included observations: 4

Cross-sections included: 92

Total pool (balanced) observations: 368

Coefficien

\begin{tabular}{|c|c|c|c|c|}
\hline \multirow[b]{2}{*}{ Variable } & \multicolumn{2}{|l|}{ Coefficien } & \multirow[b]{2}{*}{ t-Statistic } & \multirow[b]{2}{*}{ Prob. } \\
\hline & $\mathrm{t}$ & Std. Error & & \\
\hline $\mathrm{C}$ & -0.042099 & 0.123523 & -0.340816 & 0.7334 \\
\hline TA? & -0.032280 & 0.045492 & -0.709580 & 0.4784 \\
\hline RA? & -0.038787 & 0.063258 & -0.613159 & 0.5402 \\
\hline RK? & 0.082251 & 0.038225 & 2.151768 & 0.0321 \\
\hline R-squared & 0.013910 & \multicolumn{2}{|c|}{ Mean dependent var } & 0.079389 \\
\hline Adjusted R-squared & 0.005783 & \multicolumn{2}{|c|}{ S.D. dependent var } & 0.479251 \\
\hline S.E. of regression & 0.477863 & \multicolumn{2}{|c|}{ Akaike info criterion } & 1.371826 \\
\hline Sum squared resid & 83.12063 & \multicolumn{2}{|c|}{ Schwarz criterion } & 1.414305 \\
\hline Log likelihood & -248.4160 & \multirow{2}{*}{\multicolumn{2}{|c|}{$\begin{array}{l}\text { Hannan-Quinn criter. } \\
\text { Durbin-Watson stat }\end{array}$}} & 1.388703 \\
\hline F-statistic & 1.711550 & & & 1.849281 \\
\hline Prob(F-statistic) & 0.164215 & & & \\
\hline
\end{tabular}

Sumber: hasil output eviews 9

Model penelitian yang dihasilkan dari model Common Effect diatas ditunjukkan sebagai berikut:

$\mathrm{KA}=\mathbf{- 0}, 042099 \boldsymbol{- 0 . 0 3 2 2 8 0}(\mathrm{TA}) \boldsymbol{- 0 . 0 3 8 7 8 7}$ $($ RA) + 0.082251 (RK)

\section{Pengaruh Tenur Audit Terhadap Kualitas Audit (Akrual Lancar)}

Penelitian Ini Juga bertujuan untuk mengetahui pengaruh dari tenur audit terhadap tingkat akrual lancar pada perusahaan manufaktur yang terdaftar di bursa efek Indonesia. Untuk mengetahui pengaruh antara variabel tersebut peneliti menggunakan analisis regresi data panel. Tenur audit diukur dengan menghitung jumlah tahun perikatan antara auditor dengan perusahaan sampel. Hasil analisis menunjukkan bahwa variabel tenur audit berpengaruh negatif terhadap akrual lancar. Hal tersebut dibuktikan berdasarkan hasil analisis yang menunjukan bahwa nilai koefisien tenur audit sebesar $-0.032280<$ 0 , yang artinya bernilai negatif dan lebih kecil dari nol. Setiap adanya peningkatan tenur audit sebesar satu maka akan mengurangi akrual lancar sebesar 0.032280. Hasil penelitian ini menunjukkan bahwa Hipotesis nol (Ho) ditolak dan Hipotesis alternative (Ha) diterima. Hasil pengujian hipotesis menunjukkan bahwa tenur auditor berpengaruh negatif pada kualitas audit. Hal ini berarti semakin bertambahnya tenur auditor melaksanakan audit terhadap kliennya maka akan mengurangi kualitas auditnya.

Penelitian ini pun mendukung penelitian Sulthon (2015), Paramita \& Latrini (2015). Mgbame, et al.(2012), Giri (2010), dan Siregar, et al (2012) yang membuktikan secara empiris bahwa 

2011-2014)

adanya hubungan negatif antara tenur audit dengan kualitas audit. Perusahaan yang diaudit oleh auditor KAP non Big Four memiliki rata-rata tenure auditor lebih besar daripada perusahaan yang diaudit oleh auditor KAP Big Four. Hal ini menunjukkan bahwa perusahaan yang diaudit oleh auditor KAP non Big Four memiliki kecenderungan masa perikatan yang lebih panjang, sehingga dapat menyebabkan timbulnya hubungan yang terlalu dekat antara auditor dengan klien. Hubungan yang terjalin antara auditor dengan klien yang terlalu dekat dapat menurunkan sikap independensi auditor dan mengurangi profesionalisme kerja dari auditor tersebut, sehingga hasil audit rendah

Hasil penelitian ini tidak mendukung dengan hasil penelitian Saputri (2015) dan Fierdha et al (2014) dan menolak argumen bahwa semakin lama bertugas, auditor akan memiliki pengetahuan dan pengalaman untuk merancang prosedur audit yang efektif. Hasil penelitian ini juga tidak mendukung penelitian Myers et al (2003), Manry et al (2008) dan Lim \& Tan (2009) yang menemukan bahwa kualitas audit berpengaruh positif terhadap tenur. Ataupun tidak sejalan dengan penelitian Wibowo \& Rossieta (2009) dan Maharani (2014) yang menemukan bahwa tenur audit tidak berpengaruh terhadap kualitas audit.

\section{Pengaruh Rotasi Audit Terhadap Kualitas Audit (Akrual Lancar)}

Penelitian Ini Juga Bertujuan untuk mengetahui pengaruh dari rotasi audit terhadap kualitas audit (akrual lancar) pada manufaktur yang terdaftar di bursa efek Indonesia. Untuk mengetahui pengaruh antara variabel rotasi audit tersebut peneliti menggunakan analisis regresi data panel. Hasil pengujian dan pengolahan data secara statistik menunjukan bahwa nilai koefisien tenur audit sebesar $-0.038787<0$, yang artinya bernilai negatif dan lebih besar dari nol. Setiap adanya peningkatan sebesar satu pada rotasi audit maka akan mengurangi akrual lancar sebesar 0.038787. Hasil penelitian ini menunjukkan bahwa Hipotesis nol (Ho) diterima dan Hipotesis alternatif (Ha) ditolak.

Nilai koefisien untuk rotasi adalah sebesar -0.038787 dan bertanda negatif, artinya semakin tinggi nilai rotasi audit perusahaan akan mengakibatkan menurunnya peluang kualitas audit pada perusahaan. Hal ini sesuai dengan penelitian yang dilakukan oleh Siregar, dkk (2012) yang menunjukkan bahwa mandatory audit rotation tidak menunjukkan memiliki efek positif terhadap kualitas audit. Secara keseluruhan penelitian Siregar, dkk (2012) tidak ditemukan bukti kuat untuk mendukung gagasan bahwa mandatory audit rotation yang ada efektif untuk meningkatkan kualitas audit. Dengan kata lain mereka percaya bahwa hubungan yang panjang antara auditor dengan kliennya dapat meningkatkan kualitas audit. Manajemen juga cenderung menolak adanya kewajiban rotasi audit, karena adanya potensi ancaman yang bersifat menggangu, memakan waktu, dan proses yang memakan biaya untuk memilih auditor baru dan memperkenalkan mereka kepada operasi bisnis, prosedur, sistem dan industry perusahaan (AICPA, 1992).

Hasil penelitian ini juga berhasil mendukung penelitian Maharani (2014) yang menemukan bahwa rotasi audit tidak berpengaruh dan atau berpengaruh negatif terhadap kualitas audit. Walaupun demikian penelitian ini tidak mendukung penelitian Saputri (2015) dan Kurniasih \& Rohman (2014) yang menemukan bahwa rotasi audit berpengaruh positif terhadap kualitas audit.

\section{Pengaruh Reputasi KAP Terhadap Kualitas Audit (Akrual Lancar)}

Penelitian ini juga bertujuan untuk mengetahui pengaruh reputasi KAP terhadap kualitas audit (akrual lancar) pada manufaktur yang terdaftar di bursa efek Indonesia. Untuk mengetahui pengaruh antara variabel tersebut peneliti menggunakan analisis regresi data panel. 
Hasil analisis menunjukkan bahwa variabel reputasi KAP berpengaruh positif terhadap akrual lancar. Hal tersebut dibuktikan berdasarkan hasil analisis yang menunjukan bahwa nilai koefisien reputasi KAP sebesar $0.082251>0$, yang artinya bernilai positif dan lebih besar dari nol. Setiap adanya peningkatan reputasi KAP sebesar satu maka akan menambah kualitas audit sebesar 0.082251. Hasil penelitian ini menunjukkan bahwa Hipotesis nol (Ho) ditolak dan Hipotesis alternative (Ha) diterima.

Hasil penelitian ini sejalan dengan penelitian Saputri (2015) dan Choi et al (2010) yang menemukan bahwa reputasi KAP berpengaruh positif terhadap kualitas audit dan juga menguatkan pendapat Choi et al (2010) bahwa auditor besar seperti Big-4 punya tanggung jawab untuk menyediakan jasa audit dengan kualitas yang sama diantara kantor-kantor lokal (afiliasi) dengan ukuran yang berbeda dan berlokasi di berbagai macam wilayah dan negara. Tapi penelitian ini tidak sejalan dengan yang disampaikan Efraim (2010) hasil penelitian efraim bermakna bahwa berafiliasi dengan KAP internasional lebih bertujuan untuk menarik klien. Pramudji dan Trihartati (2009) menyatakan dalam hasil penelitiannya bahwa kualitas laporan keuangan auditan secara tidak langsung dipengaruhi oleh integritas auditor secara individual. Kemungkinan terjadinya manajemen laba semakin besar jika auditor secara individual memiliki integritas rendah sekalipun auditor tersebut berasal dari KAP Big-4. Alasan ini didukung oleh terlibatnya KAP Arthur Andersen dalam kasus Enron.

\section{SIMPULAN DAN SARAN Simpulan}

Berdasarkan hasil penelitian dan analisis mengenai pengaruh tenur audit, rotasi audit dan reputasi KAP terhadap kualitas audit ditinjau dari tingkat akrualnya pada perusahaan manufaktur yang terdaftar di Bursa Efek Indonesia tahun 2011-2014, maka dapat ditarik kesimpulan sebagai berikut:
1. Variabel tenur audit berpengaruh negatif terhadap kualitas audit pada perusahaan manufaktur, yang artinya semakin lama auditor KAP mengadakan perikatan audit terhadap kliennya menyebabkan berkurang kualitas auditnya . Hal ini disebabkan oleh semakin lamanya masa perikatan menyebabkan auditor akan memiliki hubungan yang terlalu dekat dan dapat menurunkan sikap independensi auditor dan mengurangi profesionalisme kerja dari auditor tersebut, sehingga hasil audit rendah. Hasil penelitian ini berhasil mendukung hipotesis.

2. Rotasi audit berpengaruh negatif terhadap kualitas audit pada perusahaan manufaktur, yang artinya semakin sering auditor melakukan rotasi audit menyebabkan berkurang kualitas auditnya. Hal ini dapat disebabkan karena dengan seringnya pergantian auditor pada sebuah perusahaan, maka akan berkurangnya juga pemahaman seorang auditor terhadap kliennya. Hasil penelitian ini tidak berhasil mendukung hipotesis.

3. Reputasi KAP berpengaruh positif terhadap kualitas audit pada perusahaan manufaktur, yang artinya semakin tinggi nilai reputasi KAP akan meningkatan kualitas audit pada sebuah perusahaan. Hal ini dapat disebabkan karena reputasi KAP yang tinggi mempunyai kemampuan yang lebih baik dalam melakukan audit, sehingga mampu menghasilkan kualitas audit yang lebih tinggi. Hasil penelitian ini berhasil mendukung hipotesis

\section{Saran}

Berdasarkan hasil penelitian dan analisis mengenai pengaruh tenur audit, rotasi audit dan reputasi KAP terhadap kualitas audit dan memperoleh kesimpulan, maka penulis mengajukan beberapa saran yang dapat dikemukakan sebagai berikut : 
1. Bagi perusahaan manufaktur yang terdaftar di Bursa Efek Indonesia diharapkan dapat meningkatkan kualitas audit perusahaan masing-masing. Selain itu, mengacu pada hasil penelitian tenur audit dan reputasi KAP mempunyai pengaruh positif terhadap kualitas audit, maka bagi perusahaan manufaktur diharapkan dapat memilih partner auditor yang berafiliasi agar dapat meningkatkan kualitas audit, karena dengan hal tersebut perusahaan dapat memperkecil resiko terhadap kerugian yang disebabkan oleh kesalahan opini atau kesalahan dalam proses pengauditan.

2. Bagi investor yang akan melakukan investasi disarankan untuk lebih cermat lagi dalam menilai keadaan dan kondisi dari sebuah perusahaan sebelum memutuskan menanamkan modal pada perusahaan tersebut.

3. Penelitian selanjutnya diharapkan dapat menambahkan atau menggunakan variabel lain yang baru agar lebih mengetahui pengaruh dari variabel independen lainnya.

4. Sampel pada penelitian ini hanya meliputi perusahaan sektor manufaktur, untuk penelitian selanjutnya diharapkan cakupan sampel penelitian ditambahkan dengan sektor perbankan, properti, atau seluruh sektor yang terdapat di Bursa Efek Indonesia.

5. Bagi peneliti selanjutnya, diharapkan dapat menggunakan proksi lain untuk mengukur kualitas audit.

\section{DAFTAR PUSTAKA}

Aliya, Angga. 2015. Laporan Keuangan Bermasalah, Inovisi Ganti Auditor. [online] tersedia finance.detik.com/read/2015/05/25/13 1118/2924038/6/laporan-keuanganbermasalah-inovisi-ganti-auditor, diakses pada 6 Februari 2016 pukul 11.30 .

Apandi, R. Nelly Nur, 2014. Relevansi Nilai, Subjektifitas Other Comprehensive
Income dan Kualitas Audit. Simposium Nasional Akuntansi 17.

Bapepam. 2002. Siaran Pers Badan Pengawas Pasar Modal Tanggal 27 Desember 2002. Jakarta

Boynton, et al. 2002. Modern Accounting. Edisi Ketujuh. Jakarta: Erlangga.

Eisenhardt, K. M. 1989. Agency Theory: An Assesment and Review. Academy of Management Review 14 (1): 57-74

Fierdha, H. Gunawan dan P. Purnamasari. 2014. Pengaruh Audit Rotation dan Audit Tenure Terhadap Kualitas Audit dengan Fee Audit sebagai Varibel Pemoderasi. Prosiding Ilmu Ekonomi Universitas Islam Bandung.

Giri, Efraim Ferdinan. 2010. Pengaruh Tenur Kantor Akuntan Publik (KAP) dan Reputasi KAP terhadap Kualitas Audit : Kasus Rotasi Wajib Auditor di Indonesia. Simposium Nasional Akuntansi 13.

Jensen, M. \& Meckling, W. (1976). Theory of the firm: Managerial behaviour, agency costs and ownership structure. Journal of Financial Economics 3 (4), 305360.

Kurniasih, Margi dan Abdul Rohman. 2014. Pengaruh Fee Audit, Audit Tenure, dan Rotasi Audit Terhadap Kualitas Audit. Diponegoro Journal of Accounting. Vol 3. No 3:1-10.

Lim, Chee-Yeow. Tan, Hun-Tong. 2009. Does Auditor Tenur Improve Audit Quality? Moderating Effects of Industry Specialization and Fee Dependence.

http://papers.ssrn.com/sol3/papers. cfm?abstract_id=1638530 diakses tanggal 10 Desember 2015.

Maharani, Adisti Putri. 2014. Pengaruh Audit Tenure, Audit Fee, Rotasi Audit dan Spesialisasi Auditor Terhadap Kualitas Audit. Jurnal 
Ekonomi dan Keuangan. Fakultas Ekonomi dan Bisnis. Universitas Muhamadiyah Surakarta.

Mgbame, C.O.,Eragbhe, E, dan Osazuwa, N. 2012. "Audit Partner Tenure and Audit Quality: An Empirical Analysis." European Journal of Business and Management, Vol.4, No.7,pp.154-159.

Myers, James N., Myers, Linda A., and Omer, Thomas C. 2003. Exploring the Term of the Auditor-Client Relationship and the Quality of Earnings: A Case for mandatory Auditor Rotation?. The Accounting Review 78(3): 779-799.

Panjaitan, C. Marshal. 2014. Pengaruh Tenure, Ukuran KAP dan Spesialiasasi Auditor Terhadap Kualitas Audit. Diponegoro Journal of Accounting. Vol. 3, No. 3:1-14.

Saputri, R. A. Sri. 2015. Pengaruh Fee Audit, Audit Tenure, Rotasi Audit, Reputasi Audit, Ukuran KAP dan Pengalaman Terhadap Kualitas Audit. Skripsi. Fakultas Ekonomi dan Bisnis Universitas Muhammadiyah Surakarta.

Siregar, Fitriany, Wibowo dan Anggraita. 2011. "Rotasi dan Kualitas Audit: Evaluasi Atas Kebijakan Menteri Keuangan

KMK.N0.423/KMK.6/2002 Tentang Jasa Akuntan Publik". Jurnal Akuntansi dan Keuangan Indonesia, Vol.8, No.1,pp.1-17.

Sopian, Dani. 2014. Pengaruh Ukuran Kantor Akuntan Publik dan Masa Perikatan Audit Terhadap Kualitas Audit serta Implikasinya Terhadap Kualitas Laba. Jurnal Sains Manajemen \& Akuntansi. Vol VI, No 1.

Tuanakota, Theodorus M. 2011. Berpikir Kritis Dalam Auditing. Jakarta: Salemba Empat.

Weiner, Jackie. 2012. Auditor Size vs Audit Quality: An Analysis of Auditor Switches. Thesis. Honors College.

Wibowo Arie dan Rossieta, Hilda. 2009. Faktor-Faktor

Determinasi
KualitasAudit-Suatu Studi Dengan Pendekatan Earnings Surprise Benchmark. Simposium Nasional Akuntansi 
IRSYAD FAUZAN P dan ROZMITA DEWI YR/ Pengaruh Tenur Audit, Rotasi Audit Dan Reputasi Kap Terhadap Kualitas Audit (Studi Pada Perusahaan Manufaktur Yang Terdaftar Di Bursa Efek Indonesia Tahun 2011-2014) 